\title{
First molecular isolation of Mycoplasma ovis from small ruminants in North Africa
}

\begin{abstract}
Authors:
Mohamed R. Rjeibi ${ }^{1}$

Mohamed A. Darghouth ${ }^{1}$

Houda Omri ${ }^{1}$

Khemaïs Souidi ${ }^{1}$

Mourad Rekik

Mohamed Gharbi

\section{Affiliations:}

${ }^{1}$ Laboratoire de Parasitologie, Université de la Manouba, École Nationale de Médecine Vétérinaire de Sidi Thabet, Tunisia
\end{abstract}

${ }^{2}$ International Centre for Agricultural Research in the Dry Areas, Amman, Jordan

\section{Correspondence to:}

Mohamed Rjeibi

\section{Email:}

medridharjeibi@yahoo.fr

\section{Postal address:}

Laboratoire de Parasitologie, École Nationale de Médecine Vétérinaire de Sidi Thabet, Université de la Manouba, 2020 Sidi Thabet, Tunisia

\section{Dates:}

Received: 30 Nov. 2014

Accepted: 21 Apr. 2015

Published: 08 June 2015

How to cite this article: Rjeibi, M.R., Darghouth, M.A., Omri, H., Souidi, K., Rekik, M. \& Gharbi, M., 2015, 'First molecular isolation of Mycoplasma ovis from smal ruminants in North Africa', Onderstepoort Journal of Veterinary Research 82(1), Art. \#912, 5 pages. http:// dx.doi.org/10.4102/ojvr. v82i1.912

\section{Copyright:}

(C) 2015. The Authors. Licensee: AOSIS OpenJournals. This work is licensed under the Creative Commons Attribution License.

\section{Read online:}

Eperythrozoonosis is a small ruminant disease caused by the bacterium Mycoplasma ovis (formerly known as Eperythrozoon ovis). Whilst acute infection in sheep may result in an anaemia and ill thrift syndrome, most animals do not develop clinical signs. Molecular methods were used to compare and evaluate the prevalence of infection with M. ovis in sheep and goats in Tunisia. A total of 739 whole blood samples from 573 sheep and 166 goats were tested for the $M$. ovis $16 \mathrm{~S}$ rRNA gene using PCR. The overall prevalence was $6.28 \% \pm 0.019(36 / 573)$. Only sheep were infected with M. ovis $(p<0.001)$, and the prevalence was significantly higher in central Tunisia $(29.2 \%)$ compared with other regions $(p<0.05)$. The prevalence revealed significant differences according to breed and bioclimatic zones $(p<0.001)$. Furthermore, the prevalence in young sheep $(35 / 330 ; 10.6 \%)$ was higher than in adults $(1 / 243 ; 0.41 \%)(p<0.001)$. Only sheep of the Barbarine breed were infected, with a prevalence of $11.8 \%(p<0.001)$. This is the first molecular study and genetic characterisation of M. ovis in North African sheep breeds.

\section{Introduction}

There are over 1.07 billion sheep in the world, $27 \%$ of which are located in Africa (Food and Agriculture Organization of the United Nations 2010). Sheep are amongst the major economicallyimportant livestock species in Tunisia, with a total population of 6.955 million heads; they play an important role in the livelihood of resource-poor farmers (Observatoire National de l'Agriculture 2006). In Tunisia, as in several other North and sub-Saharan African countries, small ruminants face harsh production conditions, which are exacerbated by both a high frequency of extreme climatic conditions and a plethora of bacterial and viral diseases with high prevalence rates of infections, such as brucellosis, border disease and peste des petits ruminants. Several parasitic diseases occur with high incidence and infection intensity, such as echinococcosis (Lahmar et al. 2013), fasciolosis (Akkari, Gharbi \& Darghouth 2011), gastrointestinal helminths (Akkari, Gharbi \& Darghouth 2012), toxoplasmosis (Gharbi et al. 2013) and piroplasmosis (M'ghirbi et al. 2013; Rjeibi, Darghouth et al. 2014; Rjeibi, Gharbi et al. 2014). This results in a very high challenge to the immune system, which is further exacerbated by long periods of food shortage during which quantitative and qualitative nutrient supplies are well below animals' requirements (Rekik, Aloulou \& Ben Hamouda 2005). All of these factors increase the impact of several pathogens.

The local sheep and goat populations in North Africa are subject to high exposure to new pathogens such as Theileria lestoquardi (Rjeibi, Darghouth et al. 2014) because of the high permeability of its borders to important flows of small ruminants from both the western and southern neighbouring countries.

Mycoplasma ovis (Eperythrozoon ovis), is a haemotropic mycoplasma that attaches to the red blood cells of sheep; it was first described by Neitz in 1934 (Neitz, Alexander \& Du Toit 1934). Mycoplasma ovis infection of sheep may cause mild to severe anaemia with a high lethality rate in lambs, whereas adults are usually chronically infected but show no clinical signs, with a low lethality rate (Grazziotin et al. 2011). Mycoplasma ovis infection is transmitted by blood-feeding arthropods and has been reported in domestic small ruminants: sheep and goats (Hornok et al. 2012; Neimark, Hoff \& Ganter 2004), in white-tailed deer (Odocoileus virginianus) and reindeer (Rangifer tarandus) (Boes et al. 2012; Stoffregen et al. 2006). Mycoplasma ovis was detected for the first time by PCR in Germany in sheep by Neimark et al. (2004); it has also been reported in Hungary (Hornok et al. 2009), Japan (Tagawa et al. 2012) and the USA (Deshuillers et al. 2014).

The 16S rRNA gene of this organism was sequenced, as described by Grazziotin et al. (2011), to determine the genetic relationship between this and other haemotropic bacterial species. Phylogenetic analysis revealed that this wall-less bacterium is not a rickettsia but rather a mycoplasma and is closely related to several other uncultivated, epi-erythrocytic mycoplasmas comprising a recently-identified group, namely the haemotropic mycoplasmas. This group 
consists of former Eperythrozoon and Haemobartonella species as well as the newly-identified epi-erythrocytic mycoplasmas (Neimark et al. 2004). The authors present the first molecular study and genetic characterisation of M. ovis in Africa from small ruminants in different regions of Tunisia (North Africa).

\section{Research method and design Small ruminant population}

This cross-sectional study was carried out on five farms located in four different Tunisian bioclimatic zones (humid, semi-arid, arid and Saharan) (Figure 1). Data related to annual rainfall, temperature, moisture and altitude in the different sampling sites are reported in Table 1. All the farms were private and traditionally managed. In Ariana and Jendouba, the production system is mainly livestockforage integrated. In Kairouan, the production system is crop-livestock relying on the use of barley and further south, in Kebili and Tataouine, the system is extensive rangelandbased. Animals mainly grazed and received various levels of supplementation (barley and bran), especially during summer and autumn. A total of 739 small ruminants consisting of 573 sheep (303 Barbarine and 270 Queue Fine de l'Ouest) and 166 goats (144 of the local breed and 22 crossbred animals) were randomly included in the survey (Table 1). The genetic type was determined according to the description of Rekik et al. (2005). Because of the lack of information on animals, they were ranked in two age groups: less and more than one year. EDTA whole blood samples were collected from each animal and stored at $-20{ }^{\circ} \mathrm{C}$ until used. All sheep included

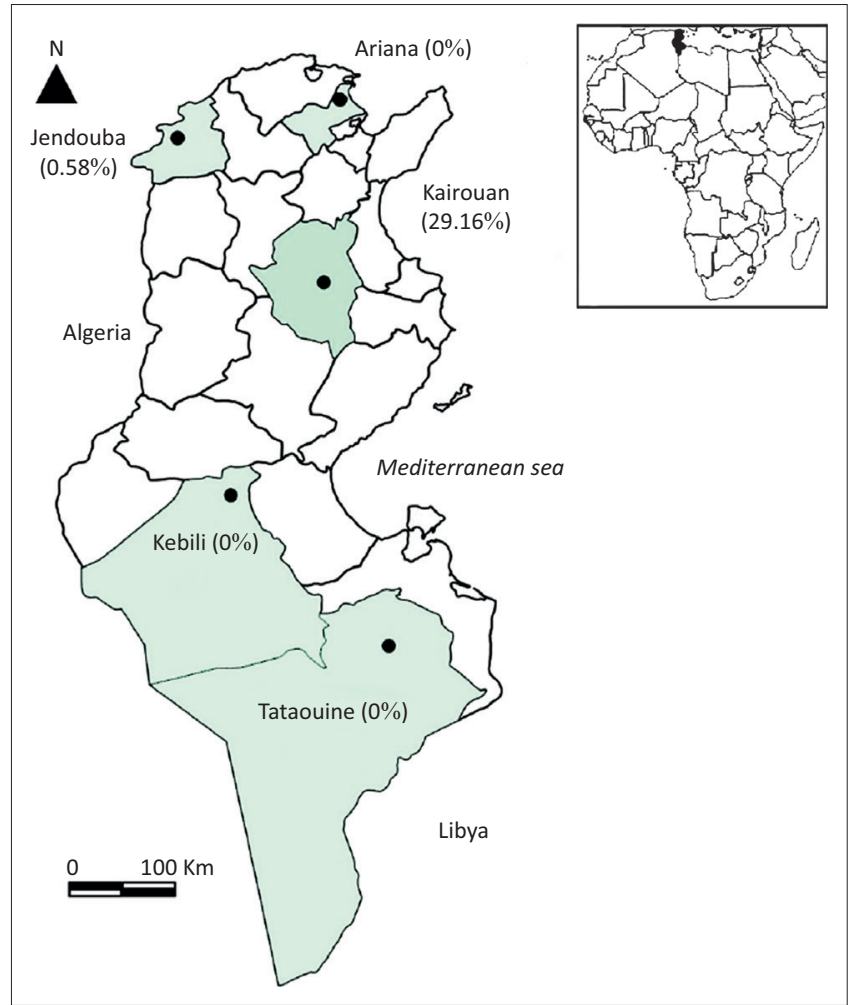

Source: Authors' creation

FIGURE 1: Sheep Mycoplasma ovis molecular prevalence in five Tunisian localities. Prevalence, as percentage, indicated between parentheses. in the current survey were examined for ticks, which were collected into labelled tubes containing 70\% ethanol. The ticks were identified under a stereomicroscope based on the key described by Walker et al. (2003). Three tick infestation indicators were determined:

- Infestation prevalence $(\%)=100 \times$ number of infested animals/total number of examined animals.

- Infestation intensity $=$ number of ticks/number of infested animals.

- Abundance $=$ number of ticks $/$ total number of examined animals.

\section{Polymerase chain reaction}

DNA was extracted from $300 \mu \mathrm{L}$ of whole blood using the Wizard ${ }^{\circledR}$ Genomic DNA purification kit (Promega, Madison, USA) according to the manufacturer's instructions and stored at $-20{ }^{\circ} \mathrm{C}$ until used. The PCR assay for M. ovis DNA detection was performed using the protocol described by Grazziotin et al. (2011), with a set of primers that amplifies a $1341 \mathrm{bp}$ region of the $M$. ovis $16 \mathrm{~S}$ rRNA gene. The forward primer was $16 \mathrm{~S}$ Fw (5'-ATG CAA GTC GAA CGA GTA GA-3') and the reverse primer was $16 \mathrm{~S}$ Rv (5'-TGA TAC TTT CTT TCA TAG TTT G-3'). The PCR mixture consisted of $5 \mu \mathrm{L}$ of $5 \mathrm{X}$ PCR buffer ( $50 \mathrm{mM}$ Tris- $\mathrm{HCl}, \mathrm{pH} 8.5 ; 50 \mathrm{mM}$ $\mathrm{NaCl}$ ), $1.5 \mathrm{mM} \mathrm{MgCl}, 0.2 \mathrm{mM}$ of each dNTP (dATP, dCTP, dGTP, dTTP), 10 pmol of each primer, 1.25 U Taq Polymerase (Vivantis, USA), distilled water and $5 \mu \mathrm{L}$ of DNA template. The DNA amplification was performed using the following programme: 4 minutes' denaturation at $95^{\circ} \mathrm{C}$, followed by 39 cycles $\left(94^{\circ} \mathrm{C}\right.$ for $1 \mathrm{~min}, 51.6^{\circ} \mathrm{C}$ for $30 \mathrm{~s}$ and $72^{\circ} \mathrm{C}$ for $\left.90 \mathrm{~s}\right)$ and a final extension at $72^{\circ} \mathrm{C}$ for $5 \mathrm{~min}$ (Grazziotin et al. 2011).

\section{DNA sequencing and phylogenetic analyses}

The Wizard SV gel and PCR clean-up system (Promega, USA) was used to purify five selected PCR products according to manufacturer's instructions. The fragments were sequenced in both directions, using the same primers as for PCR. A conventional Big Dye Terminator cycle sequencing ready reaction kit (Applied Biosystems, Foster City, CA) and an ABI3730XL automated DNA sequencer were used. The chromatograms were evaluated with ChromasPro software (version 1.7.4; Technelysium Pty Ltd 2012). The MEGA 5.1 software programme was used, as described by Tamura et al. (2011), to perform the sequence alignments, after which the GenBank database was used to compare the sequences by means of nucleotide sequence homology. Searches were made at the network server of the National Center for Biotechnology Information (NCBI) using BLAST. The phylogenetic tree was constructed by the neighbour-joining method. The dataset was resampled 1100 times to generate bootstrap values.

\section{Statistical analysis}

Prevalence was compared using the chi-square test with Epi Info 6 software (Dean et al. 2011). For major sources of variation (species, breeds, bioclimatic zones, age group), a 
TABLE 1: Geographic and abiotic characteristics of the studied Tunisian areas and corresponding Mycoplasma ovis prevalence in sheep.

\begin{tabular}{|c|c|c|c|c|c|c|c|c|c|}
\hline Region & Governorate & $\begin{array}{l}\text { Farm sheep } \\
\text { population }\end{array}$ & $\begin{array}{c}\text { Sampled } \\
\text { sheep }\end{array}$ & $\begin{array}{l}\text { Bioclimatic } \\
\text { zone }\end{array}$ & $\begin{array}{c}\text { Mean } \\
\text { altitude } \S\end{array}$ & $\begin{array}{c}\text { MAT } \dagger\left({ }^{\circ} \mathrm{C}\right) \\
(\operatorname{Min}-\operatorname{Max}) \S\end{array}$ & MAP $\ddagger(\mathrm{mm}) \S$ & $\begin{array}{l}\text { Relative humidity (\%) } \\
\text { (Min-Max) } \S\end{array}$ & Prevalence $(\%)$ \\
\hline \multirow[t]{2}{*}{ North } & Ariana & 220 & 80 & Semi-arid & 25 & $18.4(7-33)$ & 450 & $39-92$ & 0 \\
\hline & Jendouba & 534 & 172 & Humid & 800 & $18.1(8-31)$ & 1029 & $31-100$ & 0.58 \\
\hline \multirow[t]{2}{*}{ South } & Kebili & 350 & 166 & Saharan & 43 & $21.4(6-46)$ & 100 & $14-82$ & 0 \\
\hline & Tataouine & 150 & 35 & Saharan & 247 & $20.5(6-38)$ & 51 & $15-98$ & 0 \\
\hline
\end{tabular}

$\dagger$, Mean Annual Temperature; $\downarrow$, Mean Annual Precipitation; $\S$, Climatic data were gathered from Weather Online (n.d.) and Climatedata.eu (n.d.).

$*, p<0.05$

TABLE 2: Tick infestation indicators.

\begin{tabular}{|c|c|c|c|c|c|c|}
\hline \multirow[t]{2}{*}{ Tick genera } & \multirow[t]{2}{*}{ Tick species } & \multirow[t]{2}{*}{ Number of ticks } & \multicolumn{2}{|c|}{ Prevalence of infestation } & \multirow[t]{2}{*}{ Intensity of infestation } & \multirow[t]{2}{*}{ Abundance } \\
\hline & & & $n$ & $\%$ & & \\
\hline \multirow[t]{3}{*}{ Rhipicephalus } & Rhipicephalus turanicus & 127 & $69 / 573$ & 12.04 & 1.84 & 0.22 \\
\hline & Rhipicephalus sanguineus & 13 & $7 / 573$ & 1.22 & 1.86 & 0.02 \\
\hline & Rhipicephalus camicasi & 2 & $2 / 573$ & 0.35 & 1 & 0.003 \\
\hline \multirow[t]{2}{*}{ Hyalomma } & Hyalomma excavatum & 118 & $31 / 573$ & 5.41 & 3.81 & 0.2 \\
\hline & Hyalomma dromedarii & 22 & $8 / 573$ & 1.4 & 2.75 & 0.04 \\
\hline
\end{tabular}

probability below 0.05 was used as a threshold for statistical significance.

\section{Results}

\section{Tick infestation}

A total of 282 adult ticks were collected from 573 sheep (143 males and 139 females). The sex ratio (M:F) was 1.03. These ticks belonged to two genera - Hyalomma and Rhipicephalus and included Hyalomma excavatum, $H$. dromedarii, Rhipicephalus turanicus, R. sanguineus and R. camicasi. Rhipicephalus turanicus was the dominant species (45.03\%), followed by H. excavatum $(41.84 \%)(p<0.001)$. The overall prevalence of infestation had a value of $20.4 \%(117 / 573)$. The highest prevalence was observed for $R$. turanicus (12.04\%), followed by Hyalomma excavatum $(5.41 \%)$ and the lowest was reported for $R$. camicasi $(0.35 \%)(p<0.001)$. The overall intensity and abundance of infestation were 2.41 and 0.49 ticks / animal respectively. The highest intensity of infestation was observed for H. excavatum (3.81 ticks/animal), followed by H. dromedarii (2.75) and the lowest was reported for $R$. camicasi (1 tick/animal). The most abundant tick species was $R$. turanicus (0.22), followed by $H$. excavatum (0.2), whilst $R$. camicasi was the least abundant tick (0.003) (Table 2). The association between tick burden and prevalence of $M$. ovis was not significant $(p>0.05)$.

\section{Molecular prevalence of Mycoplasma ovis in Tunisian sheep and goats}

Mycoplasma ovis was only detected in 36 out of 573 sheep $(6.28 \% \pm 0.019)$. The subsequent epidemiological indicators were estimated in sheep since none of the goats were infected with $M$. ovis ( $p=0.0009)$. The regional prevalence in sheep differed significantly; the highest rate was observed in Kairouan $(35 / 120 ; 29.2 \% \pm 0.081)$, followed by Jendouba $(1 / 172 ; 0.58 \% \pm 0.0017)$ and zero in Ariana $(0 / 80)$, Kebili $(0 / 166)$ and Tataouine $(0 / 35)(p<0.001)$. There were no statistically significant differences in the prevalence of M. ovis in tick-infested and non-infested sheep $(p>0.05)$.
The $M$. ovis infection prevalence was significantly higher in young sheep $(35 / 330 ; 10.6 \%)$ than adults $(1 / 243 ; 0.41 \%)(p<$ $0.001)$. Only Barbarine sheep were infected, with a prevalence of $11.8 \%(p<0.001)$.

\section{Sequence of Mycoplasma ovis 16S rRNA gene}

Mycoplasma ovis infection was confirmed by sequencing $16 \mathrm{~S}$ rRNA from five randomly selected positive samples: one from Jendouba (North Tunisia) and four from Kairouan (Central Tunisia). Comparison of the partial sequences of 16S rRNA gene (884 bp length) revealed 99.6\% homology between the sequence from Jendouba (KJ458989) and the sequence from Kairouan (KJ458990). These two sequences showed a difference of three nucleotides at positions 238 (G/A), 731 (T/C) and 822 (T/C). The four isolates sequenced from Kairouan had 100\% homology.

Novel M. ovis 16S rRNA genotypes named MOTNSH01 and MOTNSH02 (GenBank accession number KJ458989 and KJ458990 respectively) were identified in this study. These sequences derived from northern and central Tunisia respectively; they showed $99 \%$ homology to M. ovis in Germany (AF338268) (Neimark et al. 2004), Hungary (EU165511) (Hornok et al. 2009), Japan (JF931135) (Tagawa et al. 2012) and the USA (CP006935) (Deshuillers et al. 2014) (Figure 2).

\section{Ethical considerations}

This study was conducted in accordance with relevant national and international guidelines on handling animals, taking care to respect animal welfare.

\section{Trustworthiness}

The experiment was considered to be both reliable and valid. Reliability of the study was tested by PCR using positive control DNA obtained from sheep representing the disease and confirmed by sequencing. The experimental procedures 


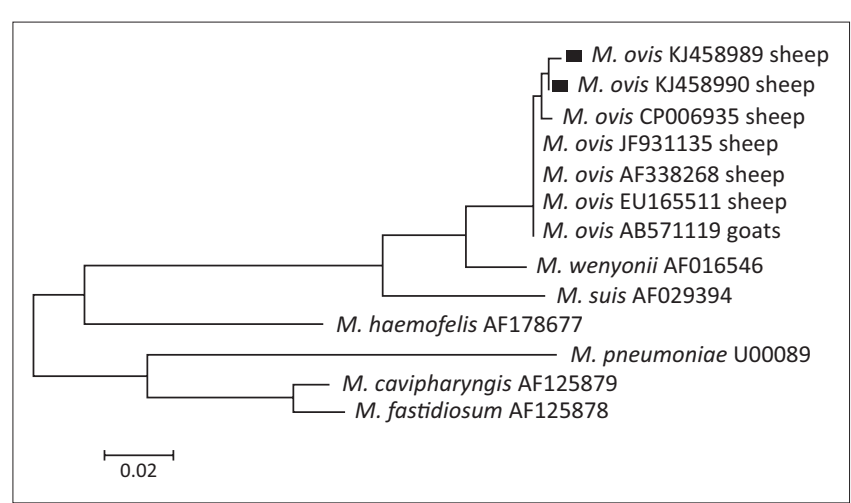

Source: Authors' creation

FIGURE 2: Partial sequence $16 \mathrm{~S}$ rRNA gene phylogenetic tree of Mycoplasma ovis identified in this survey and the main Mycoplasma species. The tree was constructed using the neighbour-joining method. The percentage of replicate trees in which the associated taxa clustered together in the bootstrap test (1100 replicates) was shown next to the branches (Felsenstein 1985). The evolutionary distances were computed using the Tamura-Nei method (Tamura \& Nei 1993) and are in the units of the number of base substitutions per site. Evolutionary analyses were conducted in MEGA5.1 (Tamura et al. 2011). Species described in this study are indicated with a black square.

were performed with care and interpretation of results was done according to the established standards.

\section{Discussion}

Mycoplasma ovis is a causative agent of haemolytic anaemia in small ruminants aged 4 weeks and older (Aguirre et al. 2009; Neimark et al. 2004), resulting in small but widespread persistent economic losses. The effect of M. ovis infection is more severe in stressful conditions when animals are infected by internal parasites or other pathogens and/or are undernourished; death may occur in severely infected lambs (Ohtake et al. 2011). Mycoplasma ovis usually causes latent infections; carriers are more susceptible to secondary infections such as those caused by Streptococcus spp., Pasteurella spp. and Eimeria spp. (Song et al. 2014).

The present molecular study was carried out to investigate M. ovis infection in small ruminants in Tunisia. The overall prevalence (6.28\%) was lower than sheep in Hungary (51.5\%) (Hornok et al. 2009), Argentina (81.8\%) (Aguirre et al. 2009) and goats in China (41\%) (Song et al. 2014). All goats sampled were negative; this could be because of: (1) a higher resistance of goats to M. ovis, (2) insufficient sample size to detect low infection prevalence or (3) the low sensitivity of the technique to very low Mycoplasma burdens. Further studies are needed to explore these hypotheses. The bacteria were detected in central Tunisia (arid region), with relatively high molecular prevalence (29.2\%). This regional discrepancy is difficult to explain but it could result from the high small ruminant density in the studied region compared to other regions, resulting in high ectoparasite burdens. Indeed, during all the visits to the farms, the presence of large numbers of biting Diptera populations was observed (results not shown). Genetic analyses showed that the analysed amplicons are closely related to all GenBank $M$. ovis sequences isolated from small ruminants, forming an independent clade. The two sequences ( $884 \mathrm{bp}$ length) presented a difference of three base pairs; it is difficult to attribute this difference to the distance between the two regions $(243 \mathrm{~km})$ or to heterogeneity in these populations.

Few data are available about $M$. ovis infection in the international literature; the clinical significance of this Mycoplasma spp. infection should be studied further. Despite the presence of an intensive uncontrolled animal trade in Tunisia, a very large difference in the prevalence was observed. The lack of information in the North African region and other surrounding sub-Saharan countries is an important gap that should be filled.

\section{Limitations of the study}

The study did not cover the whole of Tunisia; it was limited to five governorates and the findings are thus not generalisable to the country as a whole.

\section{Recommendations}

It is recommended that further studies be conducted in order to get an idea about the impact of this pathogen on small ruminants' health.

\section{Conclusion}

The present findings should encourage animal health decision makers to: (1) implement regional epidemiological surveys concerning $M$. ovis infection and (2) implement a regional animal health monitoring system to detect any increase in the prevalence of arthropod-borne diseases. Field veterinarians should include this pathogen in the differential diagnosis of arthropod-borne pathogens. The zero prevalence in the local goat population should be investigated further.

\section{Acknowledgements}

The study was supported financially by Laboratoire d'épidémiologie d'infections enzootiques des herbivores en Tunisie (Ministère de l'enseignement supérieur, de la recherche scientifique et des technologies de l'information et de la communication) and the Deutsche Forschungsgemeinschaft project 'Molecular epidemiology network for promotion and support of delivery of live vaccines against Theileria parva and Theileria annulata infection in eastern and northern Africa' (AH 41/7-1). This work was supported in part by the ICARDAled CGIAR Research Programme on Dryland Systems. The authors thank Mr Mohamed Jedidi, Dr Boubaker Ben Smida and Dr Brahim Amor for their support, as well as the farmers who agreed to let us handle their animals.

\section{Competing interests}

The authors declare that they have no financial or personal relationships which may have inappropriately influenced them in writing this article.

\section{Authors' contributions}

M.R.R. (École Nationale de Médecine Vétérinaire de Sidi Thabet [ENMV Tunisia]) was primary author of the study 
design, carried out the molecular study and performed the sequence alignment. M.G. (ENMV Tunisia) was the project leader. H.O. (ENMV Tunisia) and K.S. (ENMV Tunisia) collected samples and identified ticks. M.R. (International Centre for Agricultural Research in the Dry Areas) discussed the results and the production system framework. M.G. and M.A.D. (ENMV Tunisia) were responsible for the design of the study and writing of the manuscript. All authors read and approved the final manuscript.

\section{References}

Aguirre, D.H., Thompson, C., Neumann, R.D., Salatin, A.O., Gaido, B.A. \& de Echaide S.T., 2009, '[Clinical mycoplasmosis outbreak due to Mycoplasma ovis in sheep from Shalta, Argentina. Clinical, microbiological and molecular diagnosis]', Revisto Argentina de Microbiología 41(4), 212-214.

Akkari, H., Gharbi, M. \& Darghouth, M.A., 2011, 'Infestation of tracer lambs by Fasciola hepatica in Tunisia: Determining periods for strategic anthelmintic treatments', Revue Scientifique et Technique (Office International des Épizooties) 30(3), 917-929.

Akkari, H., Gharbi, M. \& Darghouth, M.A., 2012, 'Dynamics of infestation of tracers lambs by gastrointestinal helminths under a traditional management system in the north of Tunisia', Parasite 19(4), 407-415. http://dx.doi.org/10.1051/ parasite/2012194407

Boes, K.M., Goncarovs, K.O., Thompson, C.A., Halik, L.A., Santos, A.P., Guimaraes, A.M. et al., 2012, 'Identification of a Mycoplasma ovis-like organism in a herd of farmed white-tailed deer (Odocoileus virginianus) in rural Indiana', Veterinary Clinical Pathology 41(1), 77-83.

Climatedata.eu., n.d., Climate, viewed 13 August 2014, from http://www.climatedata.eu

Dean, A.G., Arner, T.G., Sunki, G.G., Friedman, R., Lantinga, M., Sangam, S. et al., 2011 Epi Info ${ }^{T M}$ user guide, CDC, Atlanta, GA.

Deshuillers, P.L., Santos, A.P., do Nascimento, N.C., Hampel, J.A., Bergin, I.L., Dyson, M.C. et al., 2014, 'Complete genome sequence of Mycoplasma ovis strain Michigan, a hemoplasma of sheep with two distinct 16S rRNA Genes' Genome Announcements 2(1), e01235-13. http://dx.doi.org/10.1128/ genomeA.01235-13

Felsenstein, J., 1985, 'Confidence limits on phylogenies: An approach using the bootstrap', Evolution 39(4), 783-791. http://dx.doi.org/10.2307/2408678

Food and Agriculture Organization of the United Nations, 2010, FAOSTAT, food and agriculture organization of the united nations, viewed 17 November 2013, from http://faostat3.fao.org [updated URL viewed 29 April 2015, from http://faostat3. fao.org/home/E]

Gharbi, M., Zribi, L., Jedidi, M., Chakkhari, H., Hamdi, S., R'hayem, S. et al., 2013 'Prévalence d'infection des ovins par Toxoplasma gondii en Tunisie [Prevalence
of Toxoplasma gondii infection in Tunisian sheep]', Bulletin de la Société de of Toxoplasma gondii infection in Tunisian sheep]', Bulletin de la Société de
Pathologie Exotique 106(3), 184-187. http://dx.doi.org/10.1007/s13149-013Pathologie
$0290-4$

Grazziotin, A.L., Santos, A.P., Guimaraes, A.M., Mohamed, A., Cubas, Z.S., de Oliveira, M.J. et al., 2011, 'Mycoplasma ovis in captive cervids: Prevalence, molecular characterization and phylogeny', Veterinary Microbiology 152(3-4), 415-419. characterization and phylogeny', Veterinary Micr.
$\mathrm{http} / / / \mathrm{dx}$.doi.org/10.1016/j.vetmic.2011.05.001

Hornok, S., Hajtós, I., Meli, M.L., Farkas, I., Gönczi, E., Meili, T. et al., 2012, 'First molecular identification of Mycoplasma ovis and "Candidatus M. haemoovis" from goat, with lack of haemoplasma PCR-positivity in lice', Acta Veterinaria Hungarica 60(3), 355-360. http://dx.doi.org/10.1556/AVet.2012.030
Hornok, S., Meli, M.L., Erdos, A., Hajtós, I., Lutz, H. \& Hofmann-Lehmann, R., 2009, 'Molecular characterization of two different strains of haemotropic mycoplasmas from a sheep flock with fatal haemolytic anaemia and concomitant Anaplasma from a sheep flock with fatal haemolytic anaemia and concomitant Anaplasma
ovis infection', Veterinary Microbiology 136(3-4), 372-377. http://dx.doi. ovis infection, Veterinary Microbic.
org/10.1016/j.vetmic.2008.10.031

Lahmar, S., Trifi, M., Ben Naceur, S., Bouchhima, T., Lahouar, N., Lamouchi, I. et al., 2013, 'Cystic echinococcosis in slaughtered domestic ruminants from Tunisia', Journal of Helminthology 87(3), 318-325. http://dx.doi.org/10.1017/S0022149X12000430

M'ghirbi, Y., Ros-García, A., Iribar, P., Rhaim, A., Hurtado, A. \& Bouattour, A., 2013, 'A molecular study of tick-borne haemoprotozoan parasites (Theileria and Babesia) in small ruminants in Northern Tunisia', Veterinary Parasitology 198(1-2), 72-77. http://dx.doi.org/10.1016/j.vetpar.2013.08.005

Neimark, H., Hoff, B. \& Ganter, M., 2004, 'Mycoplasma ovis comb. nov. (formerly Eperythrozoon ovis), an epierythrocytic agent of haemolytic anaemia in sheep and goats', International Journal of Systematic and Evolutionary Microbiology 54(Pt 2), 365-371. http://dx.doi.org/10.1099/ijs.0.02858-0

Neitz, W.O., Alexander, R.A. \& Du Toit, P.J., 1934, 'Eperythrozoon ovis (sp. nov.) Infection in sheep', Onderstepoort Journal of Veterinary Science 3, 263-274.

Ohtake, Y., Nishizawa, I., Sato, M., Watanabe, Y., Nishimura, T., Matsubara, K. et al., 2011, 'Mycoplasma ovis detected in free-living Japanese serows, Capricornis crispus', Journal of Veterinary Medical Science 73(3), 371-373. http://dx.doi. org/10.1292/jvms.10-0383

ONAGRI (Observatoire National de l'Agriculture), 2006, [Données concernant l'élevage ovin et caprin], Official statistics of the Ministry of Agriculture, Tunis, Tunisia.

Rekik, M., Aloulou, R. \& Ben Hamouda, M., 2005, 'Small ruminant breeds of Tunisia', in L. Iñíguez L. (ed.), Characterisation of small ruminant breeds in West Asia and North Africa, pp. 91-140, Vol. 2, North Africa, International Centre for Agricultural North Africa, pp. $91-140$, Vol. 2, North Africa, Intern
Research in the Dry Areas (ICARDA), Aleppo, Syria.

Rjeibi, M.R., Darghouth, M.A., Rekik, M., Amor, B., Sassi, L. \& Gharbi, M., 2014, 'First molecular identification and genetic characterization of Theileria lestoquardi in sheep of the Maghreb region', Transboundary and Emerging Diseases [epub ahead of print]. http://dx.doi.org/10.1111/tbed.12271

Rjeibi, M.R., Gharbi, M., Mhadhbi, M., Mabrouk, W., Ayari, B., Nasfi, I. et al., 2014, 'Prevalence of piroplasms in small ruminants in North-West Tunisia and the first genetic characterisation of Babesia ovis in Africa', Parasite 21, 23. http://dx.doi. org/10.1051/parasite/2014025

Song, W., Song, Q., He, L., Zhou, Y. \& Zhao, J., 2014, 'The establishment and application of a semi-nested PCR assay for the detection of Mycoplasma ovis', Small Ruminant Research 119(1-3), 176-181. http://dx.doi.org/10.1016/j. smallrumres.2014.03.001

Stoffregen, W.C., Alt, D.P., Palmer, M.V., Olsen, S.C., Waters, W.R. \& Stasko, J.A., 2006, 'Identification of a haemomycoplasma species in anemic reindee (Rangifer tarandus)', Journal of Wildlife Diseases 42(2), 249-258. http://dx.doi. org/10.7589/0090-3558-42.2.249

Tagawa, M., Takeuchi, T., Fujisawa, T., Konno, Y., Yamamoto, S., Matsumoto, K. et al., 2012, 'A clinical case of severe anemia in a sheep coinfected with Mycoplasma ovis and "Candidatus Mycoplasma haemovis" in Hokkaido, Japan', Journal of Veterinary Medical Science 74(1), 99-102. http://dx.doi.org/10.1292/jvms.11-0296

Tamura, K. \& Nei, M., 1993, 'Estimation of the number of nucleotide substitutions in the control region of mitochondrial DNA in humans and chimpanzees', Molecular Biology and Evolution 10(3), 512-526.

Tamura, K., Peterson, D., Peterson, N., Stecher, G., Nei, M. \& Kumar, S., 2011, 'MEGA5: Molecular evolutionary genetics analysis using maximum likelihood, evolutionary distance, and maximum parsimony methods', Molecular Biology and Evolution 28(10), 2731-2739. http://dx.doi.org/10.1093/molbev/msr121

Walker, A.R., Bouattour, A., Camicas, J.-L., Estrada-Peña, A., Horak, I.G., Latif, A.A. et al., 2003, Ticks of domestic animals in Africa: A guide to identification of species, Bioscience Reports, University of Edinburgh, Edinburgh.

Weather Online, n.d., Tableau de prévisions: Météo, viewed 13 August 2014, from http://www.wofrance.fr/weather/maps/city 